\title{
FRACTION CIPHER: A WAY TO ENHANCE STUDENT ABILITY IN ADDITION AND SUBTRACTION FRACTION
}

\author{
Mohd Afifi Bahurudin Setambah ${ }^{*}$, Anis Norma Jaafar ${ }^{1}$, Mohammad Ikhwan Mat Saad', \\ Mohd Faiz Mohd Yaakob ${ }^{2}$ \\ ${ }^{1}$ Sultan Idris Education University, Tanjong Malim, Perak, Malaysia \\ ${ }^{2}$ Universiti Utara Malaysia University, Sintok, Kedah, Malaysia
}

\begin{abstract}
Article Info
Article history:

Received Jan 7, 2021

Revised Jan 15, 2021

Accepted Jan 16, 2021

\section{Keywords:}

Design Research,

Fraction,

Fraction Addition,

Fraction Subtraction,

Mathematics Education

ABSTRACT

Learning the concept of fractions can be one of the most difficult skills to master for primary school students. Fractions are also seen to affect other mathematical knowledge, such as algebra. Researchers have introduced an innovation called Fraction Cipher to help students learn fractions. Fraction Cipher is an innovation in the arena of education that involves learning the Malay language and Mathematics. Design research is used as the research method to solve this problem consisting of three phases: preliminary design, teaching experiment, and retrospective analysis. The instruments used are fraction cipher, fraction test, and observation checklist. The results of the pair's comparative study by controlling the type I error using the Bonferroni method show that the mean values of the mathematical achievement of the experimental group and the control group are significantly different. The results show that Fraction Cipher impacts students to understand and master the concept of fractional addition and fraction subtraction operations. This research also explains the "Sake-Beda" strategy to make it easier for students to solve fractional operation problems. Besides, this study also shows the change in students' attitudes from negative to more positive. Thus, students understand and are more motivated to learn the concept of fractions.
\end{abstract}

Copyright (C) 2021 IKIP Siliwangi. All rights reserved.

\section{Corresponding Author:}

Mohd Afifi Bahurudin Setambah, Faculty of Human Development

Sultan Idris Education University, 35900 Tanjong Malim, Perak, Malaysia

Email: mohdafifi@fpm.upsi.edu.my

\section{How to Cite:}

Setambah, M. A. B., Jaafar, A. N., Saad, M. I. M., \& Yaakob, M. F. M. (2021). Fraction cipher: A way to enhance student ability in addition and subtraction fraction. Infinity, 10(1), 81-92.

\section{INTRODUCTION}

Mathematics is an appropriate instrument used to develop individual intellectual proficiency. Among the aspects that need to be developed are logical reasoning, spatial visualization, analysis and abstract thinking of students. This can be done when they learn numeracy, reasoning, thinking and problem solving skills through learning mathematics (Malaysia Education Ministry, 2014). There are various mathematical topics that students learn from year 1 to year 6 . These topics form the basis of their future mathematical development. Among the topics they studied were numbers and operations, measurements and geometry, relationships and algebra, statistics and algebra (Malaysia Education 
Ministry, 2014). Within those topics, there are smaller subtopics. For example the topics of numbers and operations contain smaller subtopics such as whole numbers, fractions, decimals, percentages and money. Therefore, this study only focuses on fractions.

Fractions have been seen as numbers that have unique properties compared to whole numbers that students have learned before. The uniqueness of its nature has made it difficult to understand (Braithwaite et al., 2018). This topic often occurs, there are four things that students often do when answering addition and subtraction fraction operation questions, namely systematic errors, random errors, negligence errors and not knowing how to answer fraction questions (Braithwaite et al., 2018; Loc et al., 2017; Purnomo et al., 2019; Salleh et al., 2013; Saparwadi et al., 2017; Tian \& Siegler, 2017).

Learning the concept of fractions can be one of the most difficult skills to master for elementary school students (Gaetano, 2014; Nurhani et al., 2018). Fractions are also seen to affect other mathematical knowledge such as algebra. This in turn will affect mathematic achievement (Siegler \& Lortie-Forgues, 2015). If viewed over a long period of time, such knowledge will also affect their mathematical ability in high school (Siegler \& Pyke, 2013). This is necessary and can be overcome through the teaching and learning process. One of the aspects that can improve students' understanding is through the use of effective teaching aids (Noh et al., 2016; Rohaeti et al., 2020). Therefore, innovation and transformation must be done through the development and construction of teaching aids. The use of teaching aids is very important so that teachers can explain things more accurately and clearly compared to oral explanations only. This can ensure that the delivery of teaching and learning can be implemented more effectively (Noh et al., 2016; Rohaeti et al., 2020).

The need to develop these teaching aids is very significant as described by Jones et al. (2011) and McNeil and Jarvin (2007). The use of aids can change the teaching and learning methods of the teacher for the better and give internal motivation to students to learn something (Gaetano, 2014). There are several teaching methods of teachers that are often practiced by mathematics teachers in order to cultivate effective teaching and learning practices. Among them are lecture methods (oral teaching and presentation of materials), discussions, inquiry methods, problem based methods, cooperative learning, project methods (Idris, 2005; Mok, 1993; Setambah, 2017). However, teachers still maintain teaching practice with the method of reviewing training answers, lectures and individual exercises while conducting math classes. This is because they are more focused on improving academic achievement (Koh et al., 2008; Mariani \& Ismail, 2013). Teachers are also said to still practice teacher-centered methods as informants and demonstrators, while students as observers and recipients of knowledge (Bahuruddin et al., 2016).

For the teaching and learning of mathematics, there are seven frequently used math teacher teaching practices. Two of the seven practices are practiced by most teachers, namely the emphasis on understanding the concept and use of the Polya model in teaching and learning. In addition, teachers also often use appropriate examples when explaining a mathematical topic. The use of easy-to-understand mathematical terms as well as existing materials has become commonplace by mathematics teachers. There are also teachers who use mind maps such as i-Think and Heuristic models during their teaching and learning sessions. Some of them also take into account the factors of students' abilities when planning their teaching and learning sessions. According to Idris (2005), there are several factors that hinder the learning of mathematics namely mind set (mind set), less effective drills, memorization before comprehension, less active student involvement, undiagnostic student doubts and unchallenged training. This has become the practice of mathematics teachers and has been identified by him while conducting research.

In conclusion, the researcher would like to emphasize that the teaching practices presented are based on several surveys conducted by researchers, especially the teaching and 
learning practices of mathematics. Therefore, teachers are expected to make transformations and reforms in order to practice teaching and learning practices that cultivate skills and increase the added value of human capital. This can be started by building the right teaching and learning materials. Innovative materials are able to give a better effect. The effect of the material being built should be tested for its effectiveness. Therefore, this study aims to identify the effects of Fraction Cipher (FC) to improve mathematical achievement for fraction topics.

Fraction Cipher (FC) (Figure 1) is an innovation in the arena of education that involves learning the Malay language and Mathematics. This absorption element is an incentive proposed by the Ministry of Education Malaysia. FC is a combination of Fraction and cipher words. The fraction is a topic chosen for improvement. Cipher is a key code used by a person for the purpose of conveying information in secret (Yeoh et al., 2015). The combination of these two words forms FC. The integration is carried out so that the concept of numerical mathematics familiar with Malay. It can improve students' vocabulary related to Malay although FC is specially developed for fractions in math. This is very well done because it can combine two subjects in one material. In other words, FC is a teaching aid that takes into account cross-curricular elements as recommended (Malaysia Education Ministry, 2014).

FC is a teaching aid in the form of board that contains the hidden words. Each board contains a specific theme. Students are required to find the hidden words in the FC board. Next the word is converted into fraction number form as in the given guide. Students are required to solve the fraction question using the concept of "Sake Beda". The group that successfully completes all the questions will move on to the next station. Fraction reinforcement process for repeated FC use by station until students successfully complete all FC themes. This teaching process begins with forming a group of students. The concept of adventure-based teaching (explore race) is used where students will move according to the checkpoint.

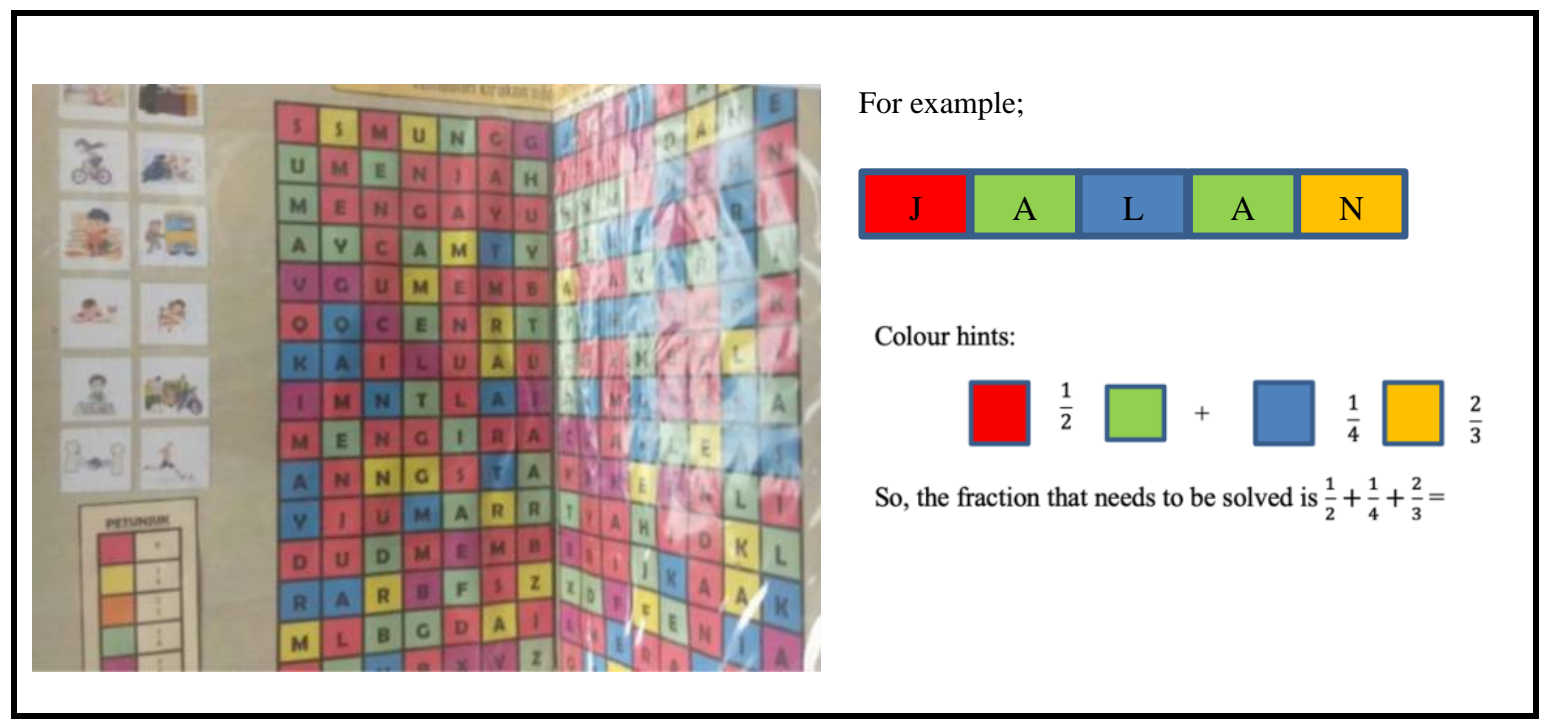

Figure 1. Fraction cipher

FC needs to be practiced using a fun learning method in order to further enhance its effectiveness through the application of the concept of gamification. Gamification is meant to combine teaching and learning fractions in math operations and the strengthening of Malay vocabulary through crossword puzzle game version of the cryptographic code. 
According to Huang and Soman (2013), gamification is a craft that produces the fun and addictive elements found in games and uses them for everyday life activities. This will help teachers attract the interest and attention of students towards the teaching and learning sessions delivered. Gamification refers to the application of game design elements to nongame activities and has been used for a variety of contexts including education (Nah et al., 2014). FC holds that the concept of learning mathematics should involve fun activities, interest in things enjoyed, students be actively involved, and involve daily life. Four of the six elements suggested by Bahuruddin et al. (2016) and Setambah et al. (2019) were applied during the construction of FC. This concept of gamification was chosen because of its good effect on improving student learning (Pradhana \& Latifah, 2013) in particular the improvement of vocabulary and fraction knowledge of students.

Apart from that, FC also uses a fun learning method which is Adventure Based Learning (ABL). Through a review of the literature that has been made, this method is rarely carried out for the purpose of learning the Malay language and mathematics. This ABL method was selected based on proven impact based on studies that can produce a student who is competitive, able to lead, improve communication skills, and help strengthen students' critical thinking skills. This method also coincides with 21 st century learning methods (Bahuruddin et al., 2016).

This innovation also emphasizes the concept of "Sake Beda". The word Sake refers to "sama=equal means permanent" while the word Beda refers to "Beza=difference mean multiply". This technique is a very important element in solving the problem of fractional basic operations among primary school students. In addition, students will also be able to add English vocabulary through this game indirectly. For example, among the words supplied such as transitive verbs are buy, give and many more. The word supplied refers to the theme of each game set. It is thus able to improve students' knowledge of the Malay language.

In conclusion, $\mathrm{FC}$ is a teaching aid development project that emphasizes some important elements. First, it involves a combination of mathematics and the Malay language. Second, applying the concept of gamification in order to increase the interest of students. Third, use the ABL method during teaching and learning. FC provides a more engaging learning environment when it incorporates two curriculum elements. FC also provides unique game learning methods that form a deep interest and motivate students. FC also forms a collaboration between students to think to complete assignments. FC emphasizes the concept of adherence to time while learning as well as emphasizing the element of discipline during learning. Finally, emphasize the concept of "Sake Beda" while performing fraction addition and subtraction operations. Therefore, it is hoped that FC will be able to give implications to students in order to improve the addition and subtraction operations for fraction topics. FC is expected to be able to impact the human capital aspects of students, especially thinking skills and leadership skills. However, this study focuses on mathematical achievement for fraction topics only.

\section{METHOD}

Design research is used as a research method. The Design Research consists of three main phases namely experimental preparation, design experimental, and retrospective analysis (Aris et al., 2017; Gravemeijer \& Cobb, 2006). There are two important aspects related to design research namely Hypothetical Learning Trajectory (HLT) and Local Instruction Theory (LIT). Learning activities as a learning path taken by students in learning activities they must have HLT and LIT. HLT consists of three components (Hendriana et al., 2019). 
In the first phase, the researcher conducted a content analysis for fraction topics. In addition, the researcher also set the objectives and purpose of teaching fractions. Then, determine the material to be used, concepts to be applied, teaching methods to be used and discuss the development of interventions to solve problems. Besides that, researchers also review the results of student training, teacher teaching sessions, and assessments instrument used by teachers. Researchers have also interviewed teachers to help with problems that arise. After identifying all of these, a FC was developed for use in the second phase. In the second phase, the researchers tested the fraction cipher with the help of a teacher and 8 students. A run test was performed as required by the researcher. The running test involves the process of improving the FC, the teaching period to be carried out, the method chosen during the use of FC. The results of the first round test were used for the purpose of improvement in the second round experiment. Researchers have found that teaching takes a long time because students are slow to find words on FC. Second, the concept of the fraction cannot be properly applied. Third, the process of teaching and learning journeys seems unsystematic during activities.

This has been overcome by setting the time of each fraction cipher and more marks are given if students can give the most and fastest answers. Researchers also introduced the concept of "Sake-Beda" to facilitate students to implement the process of addition and subtraction of fractions. Sake means "sama-kekal refer to equal value of the denominator value", so that the value of the denominator is permanent. Beda mean "beza=darab different denominator value", so student needs to multiply each other or make the denominator to equal value. Next, the researchers have arranged the student movement system according to a predetermined $\mathrm{FC}$ theme. Linear and rotation systems are used during student movement. For example, FC A will change to FC B, FC B will change to FC C, FC C will change to FC D. Eventually FC D will change to FC A. This system can help launch teaching and learning sessions using FC. After improvements were made, the second experiment was carried out smoothly. In the third phase, all data implemented during the experimental process were collected and analyzed. Analysis using descriptive statistics and inferences using Statistical Package for the Social Sciences (SPSS) software. Thus, the findings can answer the research questions and fulfill the purpose of the study that has been formed.

The intervention (Figure 2) was carried out on 30 students in which 2 groups were formed namely 15 experimental groups and 15 control groups. The experimental group was given a Fraction Cipher while the treatment group was given a conventional learning method. Students are selected based on using cluster techniques based on the following procedures: (a) Write the name of the class on a piece of paper; (b) The paper is put in a box; (c) One paper is randomly drawn; (d) The class name listed is used as a sample; (e) Students who are in the class are used as a study sample.

There are the differences between the Fraction Cipher learning method and the conventional method are as follows: (a) Teaching and learning across the curriculum for Mathematics and Malay Language for the experimental group, while the control group only learning math; (b) Learning uses FC teaching aids for experimental groups, while conventional groups do not involve FC; (c) Using adventure-based learning methods (Bahuruddin et al., 2016) for experimental group, Control group using lecture, drill and teacher-centered methods. 


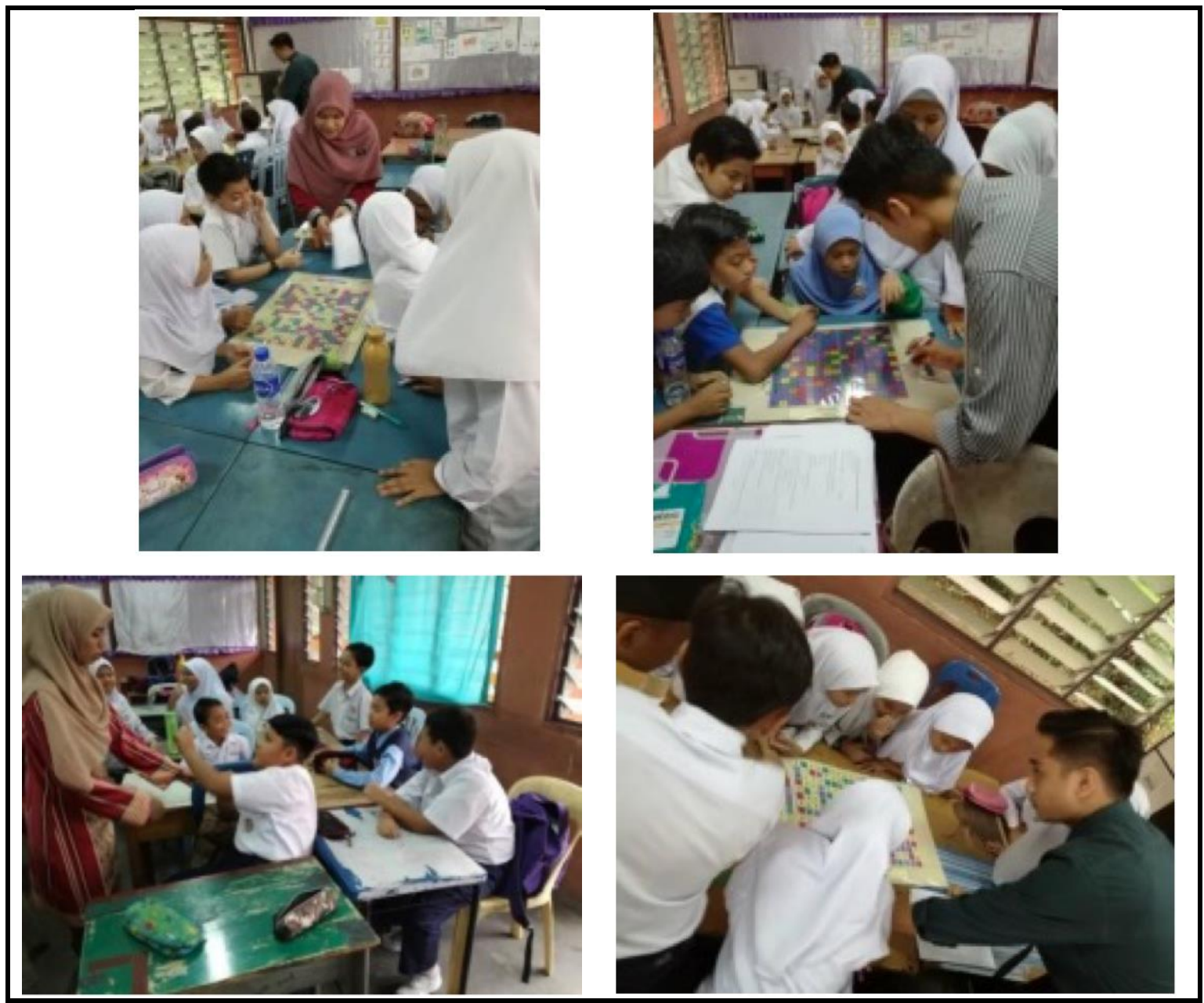

Figure 2. Implementation of fraction cipher intervention

Pre-tests were given before the intervention and post-tests were given after the intervention. Observation sessions were also conducted before and after the intervention. Students for the experimental group were divided into four groups. Each group is given a different FC theme. Students are given 15 minutes to find the hidden words on FC board. When they have finished finding the word, students need to decipher the word based on color. Each color found in FC represents a fractional value. For example, the color yellow represents value $1 / 2$. red represents value 0 . Students are then asked to sum up or subtract fractions depending on the decipher they do. The concept of "Sake Beda" is used during the process of addition and fraction breakdown. Students are given marks based on the number of hidden words found and the implementation of correct and accurate addition and subtraction operations. This intervention process was carried out repeatedly using FC for 4 weeks. This means that students are given interventions during that period.

\section{RESULTS AND DISCUSSION}

The learning that is implemented is to overcome the problem of students who have problems in addition and subtraction of fractions. The study began with a review and observation of the students. When investigated the main cause of their errors is lack of understanding of the process involved, difficulty in subtracting fractions, difficulty converting fractions to the same denominator, errors in calculations, difficulty converting 
improper fractions to mixed numbers and using incorrect processes. Students' errors in the process of adding fractions are shown through Figure 3. This occurs when misconceptions occur from one concept to another. Students found to have brought the concept of operations of addition of whole numbers to the addition topic fraction. This can be seen through the answers to questions 1, 2, 3, 4, 6, 7 and 8 that students provide. They were found to add numerators and numerators, as well as denominators and denominators. This clearly shows that a misconception has happened to them. The same thing happens when researchers review student exercises in subtraction operation. This review is similar to the study that has been conducted by Salleh et al. (2013). The Results should include the rationale or design of the experiments as well as the results of the experiments. Results can be presented in figures, tables, and text.

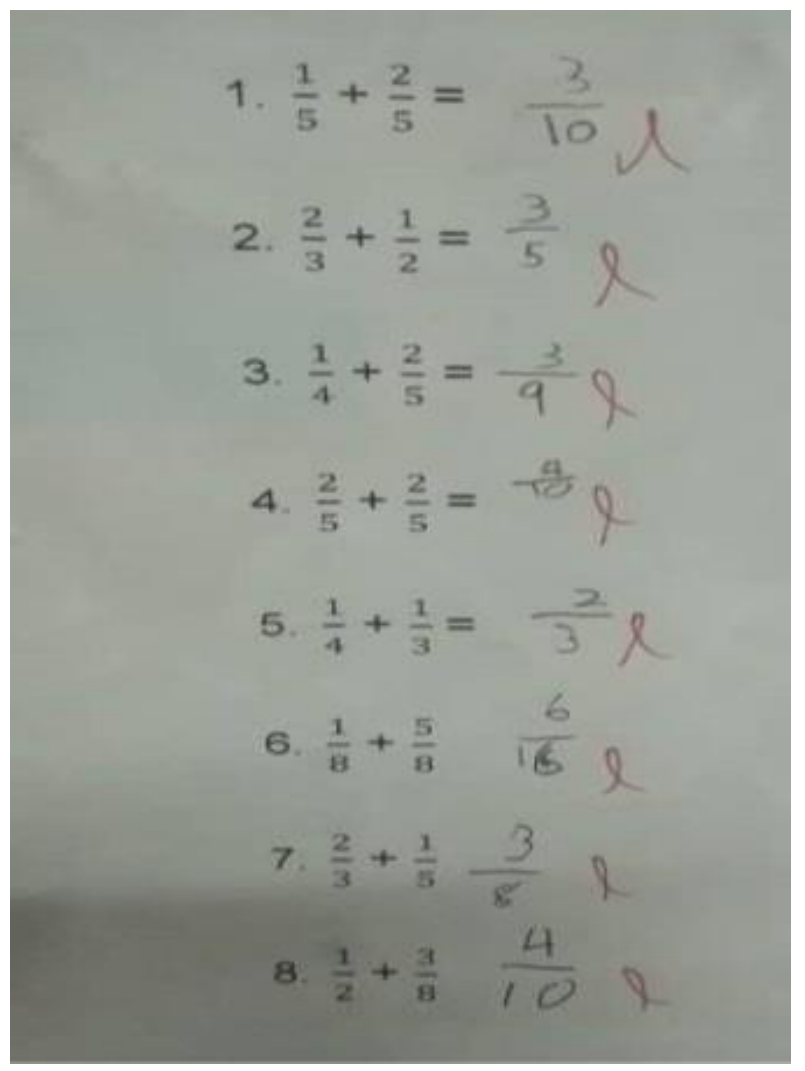

Figure 3. Student error on the process of addition of fractions

When the researchers reflect back, the researchers also found that the methods that the researchers implemented during the teaching and learning sessions did not have a positive impact on them. Researchers simply use examples and write step-by-step operations of addition and subtraction fractions without the help of teaching aids. This can be seen in the effect when researchers often find that students always complain of misunderstanding, re-ask the process of addition and subtraction of fractions This can be recorded through the expression of their words such as "I do not understand the teacher", "then how is the teacher", "Ouch, why cannot be like that teacher". This proves that they often rely on the teacher's answers and no longer understand the concepts that have been taught by their teacher.

Findings show that students have an improvement in their learning for the topic of addition and subtraction of fractions. These findings can be seen through Figure 4. Significant improvement can be seen through students 4 , students 5 , students 7 , students 8 and students 15 . This shows that FC is able to have a good impact on students. The findings 
of this study are in line with the study Aris et al. (2017) that the intervention process enhances student interest is able to have a positive impact on student mathematical achievement.

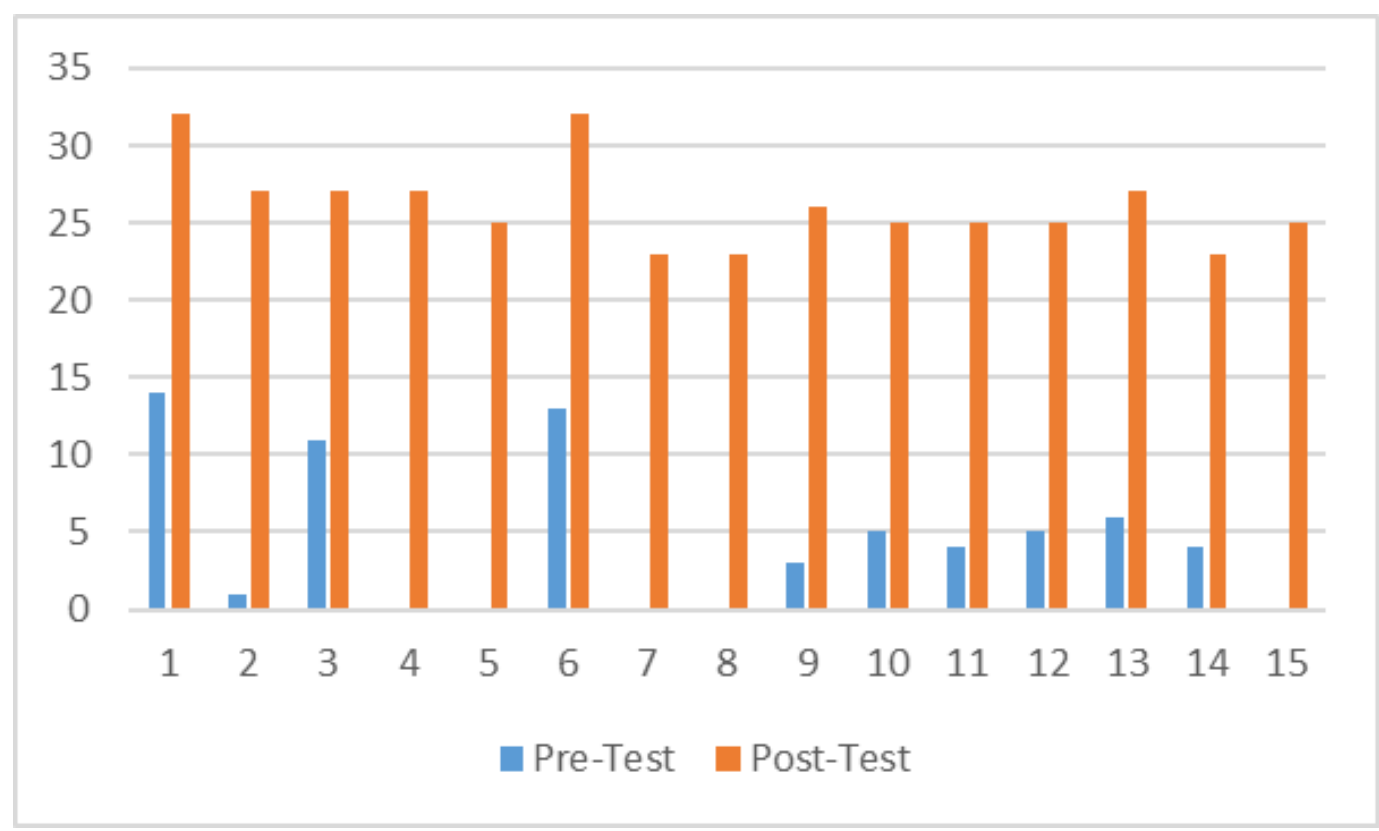

Figure 4. Differences of pre-test and post-test of experimental group

Comparisons between the experimental group and the control group were also performed through t-test. The findings show that there is a significant difference $[F(1,28)=4.61, p<0.05]$ with large effect size based on value partial eta square $=0.141$ (Cohen et al., 2007). The mean of the experimental group was higher than that of the control group. The results of the comparative analysis of the pair by controlling the type I error using the Bonferroni method show that the mean values of the mathematical achievement of the experimental group and the control group are significantly different (mean difference $=4.2$, $\mathrm{p}<0.05)$. The results of this study further strengthen the findings of the study of Noh et al. (2016) which shows that innovative teaching aids can have an impact on student achievement.

Observation findings also indicate a change in good behavior. This study coincides with the study of Jones et al. (2011) and McNeil and Jarvin (2007) when FC had a positive impact on student attitudes. Before the intervention is performed. Students were found to exhibit negative behaviors such as (1) talking unrelated to the topic, (2) thinking elsewhere (chestnuts), (3) walking from one place to another, (4) doing other work, (5) interrupting other students physically, (6) try to attract attention, (7) sharpen a pencil and (8) leave the classroom. After the intervention is implemented, negative behavior can be reduced from $40 \%$ to $10 \%$. This can be seen more clearly through the observation table made by the researcher. Table 1 shows the observations that were made before the intervention was performed. For example, student 1, negative behavior is reduced to $10 \%$. Student 2 reduced by $20 \%$. 
Infinituty Volume 10, No 1, February 2021, pp. 81-92

Table 1. Observation of student behavior

\begin{tabular}{|c|c|c|c|c|c|c|c|c|c|c|c|}
\hline \multirow{2}{*}{ Student } & \multicolumn{10}{|c|}{ Observation } & \multirow{2}{*}{ Percentage } \\
\hline & 1 & 2 & 3 & 4 & 5 & 6 & 7 & 8 & 9 & 10 & \\
\hline 1 & 3 & 4 & & & 3 & & & 8 & & & $40 \%$ \\
\hline 2 & 2 & & & & & & 2 & & & 2 & $30 \%$ \\
\hline 3 & 2 & 1 & & & 4 & & 4 & & & & $40 \%$ \\
\hline 4 & 1 & & & 1 & & & 4 & 4 & & & $40 \%$ \\
\hline 5 & & & 7 & & 4 & 4 & & & & & $30 \%$ \\
\hline 6 & & & 6 & & & & & & & & $10 \%$ \\
\hline 7 & & & 5 & & & & & & & & $10 \%$ \\
\hline 8 & & 1 & 5 & 5 & & & & & & & $30 \%$ \\
\hline 9 & 1 & 1 & 1 & 1 & & & & & 8 & 1 & $60 \%$ \\
\hline 10 & 1 & & & & & & & & & & $10 \%$ \\
\hline 11 & 3 & & & & & 7 & & 2 & & & $30 \%$ \\
\hline 12 & & 1 & & 2 & 2 & & & & & & $30 \%$ \\
\hline 13 & & 3 & & & & 3 & & & & 5 & $30 \%$ \\
\hline 14 & & 1 & & & & & & & & & $10 \%$ \\
\hline 15 & & 2 & & 3 & & & & & & & $20 \%$ \\
\hline
\end{tabular}

Researchers also conducted interviews on teachers who had been exposed to FC (Figure 5).

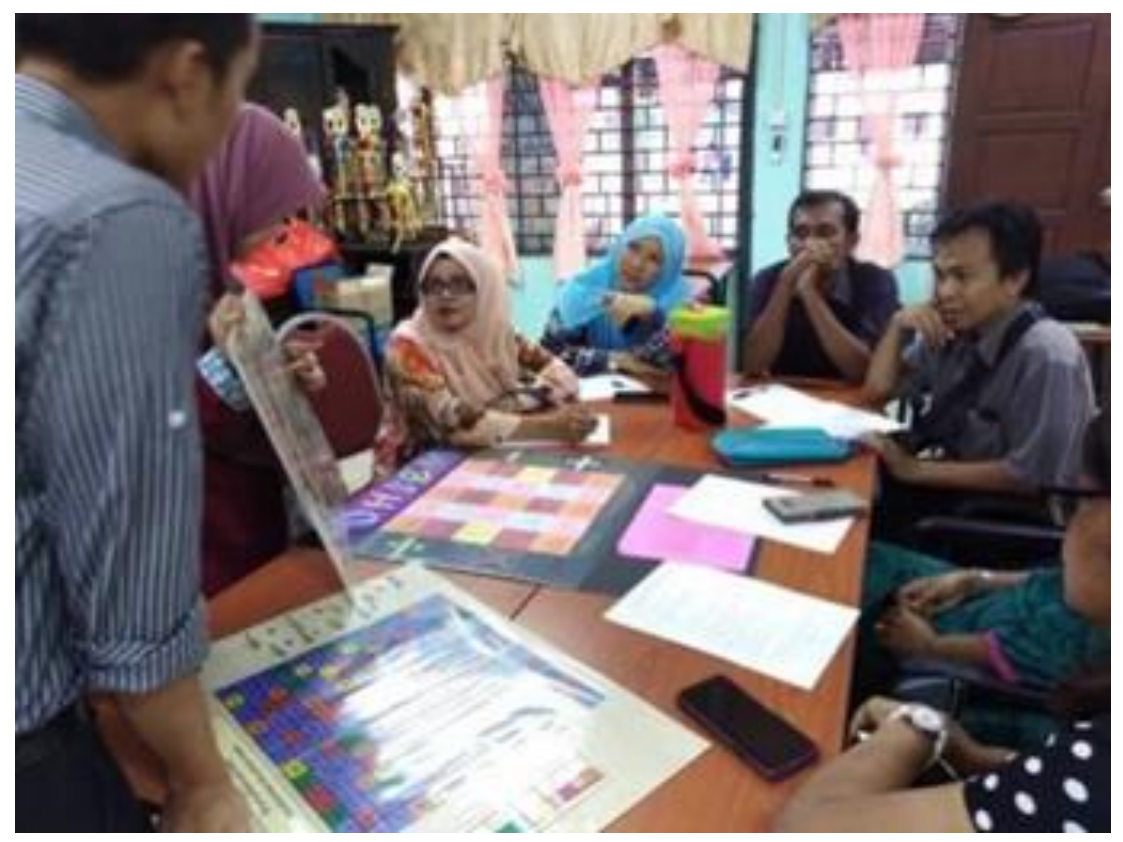

Figure 5. Discussion with mathematics teacher

The results of interviews with teachers found that FC has attracted their interest. They think that FC is a good innovation. They also stated that FC is able to give them a difference in terms of teaching and learning. FC changed the teacher-centered approach to the student- 
centered approach. They feel excited and want to use FC in their teaching and learning. Teaching aids give a good impact on teaching methods. Thus, FC gives a good perception on teachers and students. FC is seen to have a good impact on students (Noh et al., 2016).

\section{CONCLUSION}

Learning operations of addition and subtraction of fractions using the $\mathrm{FC}$ have a positive impact on students in terms of understanding, interest and motivation. This study also proves that the construction of mathematical concepts is not seen as something that needs to be moved passively, but rather needs to be built by students actively through concrete experience. In general, this study successfully solves the problem of student learning from the aspect of fractions, especially in addition and subtraction operations. Through this FC-based learning, it is hoped that the six mistakes that students often make while completing the addition and subtraction operations of fractions can also be reduced. Such errors are such as lack of understanding of the process involved, difficulty in converting to the same denominator before performing addition operations, errors in calculation, and difficulty in converting improper fractions to mixed numbers. FC is expected to have positive implications on the mission and aspirations of Malaysian education. FC is seen to have other potentials such as providing more enjoyable teaching and learning methods for teachers, providing useful experiences to students, enhancing student cooperation during group activities, improving student concentration style to find words, changing student character to be punctual and disciplined according to game rules and improve thinking skills through reasoning. Future studies can be conducted to determine these various aspects.

\section{REFERENCES}

Aris, R. M., Putri, R. I. I., \& Susanti, E. (2017). Design study: Integer subtraction operation teaching learning using multimedia in primary school. Journal on Mathematics Education, 8(1), 95-102. https://doi.org/10.22342/jme.8.1.3233.95-102

Bahuruddin, M. A., Tajudin, N. M., \& Adnan, M. (2016). Walking, explore race and flying fox adventure activity in learning statistics: Effect on leadership skills. Jurnal Didaktik Matematika, 3(2), 1-8.

Braithwaite, D. W., Tian, J., \& Siegler, R. S. (2018). Do children understand fraction addition? Developmental Science, 21(4), e12601. https://doi.org/10.1111/desc.12601

Cohen, L., Manion, L., \& Morrison, K. (2007). Research Methods In Education (6th ed.). Abingdon: Routledge Taylor \& Francis Group.

Gaetano, J. (2014). The effectiveness of using manipulatives to teach fractions. Rowan University.

Gravemeijer, K., \& Cobb, P. (2006). Design research from a learning design perspective. In Educational design research (Vol. 1, p. 17). London: Routledge.

Hendriana, H., Prahmana, R. C. I., \& Hidayat, W. (2019). The innovation of learning trajectory on multiplication operations for rural area students in Indonesia. Journal on Mathematics Education, 10(3), 397-408. https://doi.org/10.22342/jme.10.3.9257.397-408

Huang, W. H.-Y., \& Soman, D. (2013). A practitioner's guide to gamification of education. Toronto: Rotman School of Management, University of Toronto. 
Idris, N. (2005). Pedagogi dalam pendidikan matematik. Kuala Lumpur: Utusan Publication \& Distributors Sdn Bhd.

Jones, B. D., Uribe-Florez, L. J., \& Wilkins, J. L. M. (2011). Motivating mathematics students with manipulatives: Using self-determination theory to intrinsically motivate students. Yearbook (National Council of Teachers of Mathematics), 73, 215-227.

Koh, L. L., Choy, S. K., Lai, K. L., Khaw, A. H., \& Seah, A. K. (2008). Kesan pembelajaran koperatif terhadap sikap dan pencapaian Matematik bagi murid-murid sekolah rendah di sekitar bandar Kuching. Jurnal Penyelidikan IPBL, 8, 50-64.

Loc, N. P., Tong, D. H., \& Chau, P. T. (2017). Identifying the concept fraction of primary school students: The investigation in Vietnam. Educational Research and Reviews, 12(8), 531-539. https://doi.org/10.5897/ERR2017.3220

Malaysia Education Ministry. (2014). Dokumen standard kurikulum dan pentaksiran matematik tahun 6 KSSR. Putrajaya: Malaysia Education Ministry.

Mariani, A., \& Ismail, Z. (2013). Pengaruh kompetensi guru matematik ke atas amalan pengajaran kreatif. 2nd International Seminar on Quality and Affordable Education (ISQAE 2013), 181-187.

McNeil, N., \& Jarvin, L. (2007). When theories don't add up: disentangling he manipulatives debate. Theory into Practice, 46(4), 309-316. https://doi.org/10.1080/00405840701593899

Mok, S. S. (1993). Pengajaran matematik untuk kursus perguruan. Kuala Lumpur: Kumpulan Budiman Sdn Bhd.

Nah, F. F.-H., Zeng, Q., Telaprolu, V. R., Ayyappa, A. P., \& Eschenbrenner, B. (2014). Gamification of education: a review of literature. International Conference on Hci in Business, 401-409. https://doi.org/10.1007/978-3-319-07293-7_39

Noh, M. A. M., Ilias, M. F., Husain, K., Sulaiman, M. S., \& Abdullah, M. (2016). Inisiatif dan usaha guru dalam meningkatkan pengetahuan semasa penggunaan bahan bantu mengajar. E-Bangi, 13(4), 133-144.

Nurhani, S., Ghani, A., \& Mistima, S. (2018). Misconception of fraction among middle grade year four pupils at primary school. Research on Education and Psychology, 2(1), 111-125.

Pradhana, D. Y., \& Latifah, L. (2013). Pengaruh kosa kata bahasa Inggris, dasar komputer dan akuntansi terhadap prestasi belajar MYOB. Dinamika Pendidikan, 8(2), 75-84.

Purnomo, Y. W., Widowati, C., \& Ulfah, S. (2019). Incomprehension of the Indonesian elementary school students on fraction division problem. Infinity Journal, 8(1), 57. https://doi.org/10.22460/infinity.v8i1.p57-74

Rohaeti, E. E., Fitriani, N., \& Akbar, P. (2020). Developing an interactive learning model using visual basic applications with ethnomathematical contents to improve primary school students' mathematical reasoning. Infinity Journal, 9(2), 275-286. https://doi.org/10.22460/infinity.v9i2.p275-286

Salleh, Z., Saad, N. M., Arshad, M. N., Yunus, H., \& Zakaria, E. (2013). Analisis jenis kesilapan dalam operasi penambahan dan penolakan pecahan. Jurnal Pendidikan Matematik, 1(1), 1-10. 
Saparwadi, L., Purnawati, B., \& Erlian, Baiq, P. (2017). Kesalahan siswa dalam menyelesaikan soal operasi penjumlahan pada bilangan pecahan dan reversibilitas. JPM : Jurnal Pendidikan Matematika, 3(2), 60. https://doi.org/10.33474/jpm.v3i2.715

Setambah, M. A. B. (2017). Pembangunan dan pengujian modul pengajaran berasaskan adventure terhadap pencapaian matematik, kemahiran berfikir kritis dan kemahiran kepimpinan. Tg Malim: Universiti Pendidikan Sultan Idris.

Setambah, M. A. B., Tajudin, N. M., Yaakob, M. F. M., \& Saad, M. I. M. (2019). Adventure learning in basics statistics: Impact on students critical thinking. International Journal of Instruction, 12(3), 151-166.

Siegler, R. S., \& Lortie-Forgues, H. (2015). Conceptual knowledge of fraction arithmetic. Journal of Educational Psychology, 107(3), 909-918. https://doi.org/10.1037/edu0000025

Siegler, R. S., \& Pyke, A. A. (2013). Developmental and individual differences in understanding of fractions. Grantee Submission, 49(10), 1994-2004. https://doi.org/10.1037/a0031200

Tian, J., \& Siegler, R. S. (2017). Fractions learning in children with mathematics difficulties. Journal of Learning Disabilities, 50(6), 614-620. https://doi.org/10.1177/0022219416662032

Yeoh, C. L., Setambah, M. A. B., Ket, L. L., \& Sing, N. (2015). Aplikasi matematik. Bangi: Pelangi Professional Publishing Sdn. Bhd. 